\title{
BMJ Open Effects of drug price reduction and prescribing restrictions on expenditures and utilisation of antihypertensive drugs in Korea
}

\author{
Ki-Bong Yoo, ${ }^{1}$ Sang Gyu Lee, ${ }^{2,3}$ Sohee Park, ${ }^{2,3}$ Tae Hyun Kim,, ${ }^{2,3}$ \\ Jeonghoon Ahn, ${ }^{4}$ Mee-Hyun Cho, ${ }^{5}$ Eun-Cheol Park ${ }^{2,6}$
}

To cite: Yoo K-B, Lee SG, Park $\mathrm{S}$, et al. Effects of drug price reduction and prescribing restrictions on expenditures and utilisation of antihypertensive drugs in Korea. BMJ Open 2015;5: e006940. doi:10.1136/ bmjopen-2014-006940

- Prepublication history and additional material is available. To view please visit the journal (http://dx.doi.org/ 10.1136/bmjopen-2014006940).

Received 20 October 2014 Revised 23 May 2015 Accepted 17 June 2015

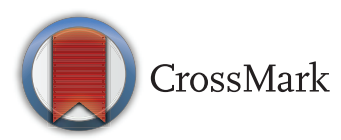

For numbered affiliations see end of article.

Correspondence to Dr Eun-Cheol Park; ecpark@yuhs.ac

\section{ABSTRACT}

Objectives: To evaluate the quantitative effects of the drug price reduction on pharmaceutical expenditures and the new guidelines to restrict prescribing on drug utilisation for antihypertensive drugs.

Design: We used an interrupted time series design with the National patient sample data of Health Insurance Review and Assessment Service in South Korea.

Methods: 54295 participants who were with primary hypertension from the National patient sample data of Health Insurance Review and Assessment Service were included. The study period was from March 2011 to December 2013. The dependent variables were antihypertensive drug costs, antihypertensive drug cost per prescribing day, daily drug utilisation, average number of drugs per month, percentage of original drugs per prescription, drug overutilisation and prohibited combinations. Segmented regression analysis was used.

Results: The drug price reduction reduced expenditure (US\$-1.51, $-10.2 \%$ ), and the new guidelines reduced expenditures even more (US\$ $-2.13 ;-16.2 \%)$. These policies saved US $\$ 4.22(28 \%)$ of antihypertensive drug costs per patient in December 2013 compared to March 2012. Drug price reduction policy was introduced in April 2012. We established the policy effect by comparing it before (March 2012) with after(21 months later-December 2012). The effects of the guidelines decreased expenditures, daily drug utilisation and the average number of drugs per month more than did the drug price reduction.

Conclusions: Both policies saved money. The guidelines were more effective over time and had fewer side effects such as increasing daily drug utilisation and number of drugs than the effects of drug price reduction.

\section{INTRODUCTION}

The increasing pharmaceutical expenditures are the one of the biggest healthcare issues in Korea. The average annual pharmaceutical

\section{Strengths and limitations of this study}

- In this study, it is possible to compare the effects of two drug policies for expenditures, the drug price reduction and the new guideline, which is prescribing restrictions, with national representative data.

- The reduction of expenditures by the drug price reduction was greater than the new guidelines at the policy initiation.

- The new guidelines had less side effects such as increasing daily drug utilisation and number of drugs than the drug price reduction, which is a direct price control.

- The 9-month overall effect of the new guidelines reduced expenditures and some drug utilisation variables more effectively than did the drug price reduction.

- This study identified only for drug utilisation and pharmaceutical expenditures. The health outcomes were not evaluated in this study.

expenditure per capita kept increasing from 2000 to 2011. The increasing rate was $9.8 \%$ from 2000 to 2009 , and $5.4 \%$ from 2009 to 2011. These rates were higher than for most of the Organisation for Economic Co-operation and Development (OECD) countries. ${ }^{1}$ As a result, expenditure on pharmaceuticals in Korea was $21.3 \%$ of total healthcare expenditure in 2011 versus an average rate of $16.4 \%$ among OECD countries'.

Recently, the Korean government introduced several pharmaceutical policies to limit the increases in pharmaceutical expenditures as well as seeking to improve the quality of care. $^{2}$ This included policies around the pricing system and guidelines for the management of patients with hypertension. One policy is that the Korean government reformed the drug pricing system and reduced the prices of existing drugs by 
rules of the reformed drug pricing system in April 2012. The other relates to the guidelines which are the prescribing restrictions for antihypertensive drugs in January $2013 .^{3}$

The previous system priced each drug according to its order of registration. For example when pricing generic drugs after patent expirations, the later a generic drug was registered, the lower was its price (see online supplementary file 1). ${ }^{4}$ The Korean government introduced a new pricing system to improve the previous pricing system. Its goals are as follows: to reduce pharmaceutical expenditures, increase accessibility of drugs, decrease the burden of health insurance premiums, block companies' rebate activities ${ }^{5}$ and improve competitiveness among Korean pharmaceutical companies. ${ }^{6}$ This reform was applied to 13184 listed drugs on the positive list. Prices for 6504 drugs were reduced, which led to a $14.2 \%$ reduction in the price of listed drugs (figure 1). ${ }^{78}$

Hypertension is the most prevalent chronic disease in Korea, with $29 \%$ of individuals aged over 30 years affected in 2012. ${ }^{9}$ One previous research reported that the primary physician's blood pressure control was poor in Korea. ${ }^{10}$ The Korean government introduced guidelines for antihypertensive drugs. It was developed to restrict prescribing and was focused on prescription and reimbursement to control drugs overutilisation and improper prescriptions. The Korean government examined research papers and other guidelines to define the proper prescription of 1112 antihypertensive drugs (box 1). ${ }^{8}$ There are penalties for physicians who do not follow the guidelines. The Korean national health insurer does not reimburse the excess over the guidelines. This penalty lowers the healthcare provider's evaluation scores which decide monetary incentives.

If physicians do not follow the guidelines, they have to pay a penalty and the government does not pay the excess portion.

The drug price reduction and the new guidelines are different; the drug price reduction is a kind of direct price control policy and the new guidelines is a prescribing restriction policy on utilisation. The objectives of this study are to evaluate the quantitative effects of the drug price reduction and the new guidelines on the drug price reduction and pharmaceutical expenditures.

\section{Backgrounds in Korea}

The Korean National Health Insurance system achieved universal coverage for the population in $1989 .{ }^{11}$ There are two types of insurance: health insurance and Medical aid. Medical aid is a type of health insurance for low-income people, like Medicaid in the USA. ${ }^{12}$ There are 1.61 million Medical aid beneficiaries, equivalent to $3.2 \%$ of the population of Korea in $2011 .^{9}$ Type 1 Medical Aid beneficiaries can use free inpatient services, and outpatient services with a \$1-\$3 copayment. Type 2 Medical aid beneficiaries must make a copayment of $10 \%$ of inpatient medical costs, $15 \%$ of medical costs for hospital-based outpatient services, approximately $\$ 2$ for clinic-based outpatient services and approximately $\$ 1$ for drug costs. Health insurance beneficiaries copay $30 \%$ of drug costs.

The most of payments made under the Korean reimbursement system is the regulated fee-for-service payment. A diagnosis-related group payment method is used for seven diseases. ${ }^{13}$ To manage payments for drugs, Korea implemented the positive list system. ${ }^{2}$

\section{METHODS}

\section{Data and study population}

This study used the National Patient Sample (NPS) data for hypertension from Health Insurance Review and Assessment Service reimbursement data. In this data, prescription data for antihypertensive drugs were included. The study period was from March 2011 to December 2013. The sample included 57150 participants, which were $1 \%$ of the randomly sampled, anonymised hypertensive patients from national hypertensive patients. Only patients with primary hypertension were included. A total of 54295 participants were included in this study. Data from January and February 2011 were excluded because of missing drug utilisation data. In this analysis, the guidelines began in February 2013, as there was a 1-month lagged effect after implementation of the new guidelines.

\section{Dependent variables}

Dependent variables were classified into two categories: drug utilisation and pharmaceutical expenditures. For drug utilisation, daily drug utilisation, average number of drugs per month, percentage of original drugs per prescription, drug overutilisation and prohibited combinations were included in the analysis. Daily drug utilisation represented how many participants took antihypertensive drugs per day. Daily dosage was adjusted by DDD. DDD indicates daily dose, which is defined by the WHO. ${ }^{14}$ A (daily drug utilisation=1) indicated that the daily dosage was equal to DDD. If daily drug utilisation was over one, participants took overdoses of their drugs more than the DDD. The percentage of original drugs per prescription was calculated as (the number of original antihypertensive drugs/the number of all antihypertensive drugs $\times 100$. The drug overutilisation and prohibited combination variables were binary. The number of drug overutilisations indicates how physicians violated the guidelines by prescribing more than two agents per ingredient. It is restricted by the new guideline; for example, two $\beta$-blockers cannot be prescribed at at one outpatient visit. The number of prohibited combinations indicates how physicians violated the prohibited combinations clause in the guideline, such as diuretic $+\alpha$ blocker (box 1). Antihypertensive drug costs per month and antihypertensive drug cost per prescribing day were included. An exchange rate of $1000 \mathrm{KRW}$ is around US $\$ 1$. 
Figure 1 Estimated drug prices after policy change (after April 2012). ${ }^{8}$

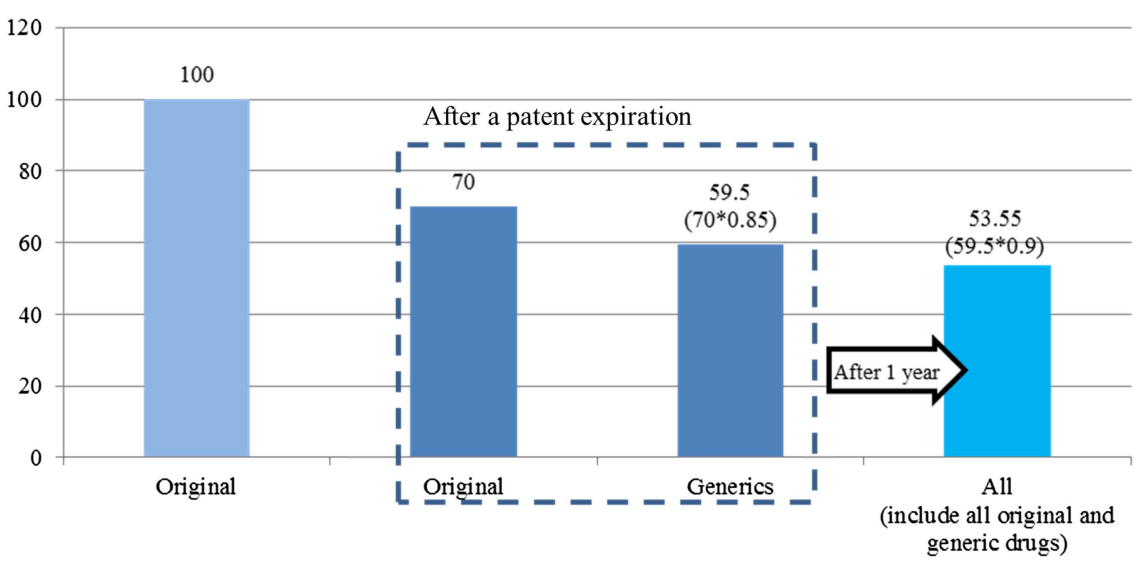

\section{Independent variables}

Age, sex, region, insurance type, Charlson comorbidity index (CCI) and combinations of antihypertensive agents

Box 1 Prescription and reimbursement guideline for hypertensive drugs $^{8}$

Antihypertensive drugs administered to hypertensive patients without comorbidity are allowed under the following conditions and reimbursement is provided if the conditions below are met.

Prescription and reimbursement guidelines for antihypertensive drugs

A. Time for administering drugs.

1. If systolic blood pressure is over $140 \mathrm{~mm} \mathrm{Hg}$ or diastolic blood pressure is over $90 \mathrm{~mm} \mathrm{Hg}$, administration of drugs is allowed.

2. Patients without risk factors for cardiovascular disorders should be advised to improve lifestyle first.

B. Rules for drug administration.

1. Only one antihypertensive agent should be administered first. If systolic blood pressure is over $160 \mathrm{~mm} \mathrm{Hg}$ or diastolic blood pressure is over $100 \mathrm{~mm} \mathrm{Hg}$, two more antihypertensive agents can be administered instead of one antihypertensive agent.

2. Even after antihypertensive agents have been administered, if systolic blood pressure is over $140 \mathrm{~mm} \mathrm{Hg}$ or diastolic blood pressure is over $90 \mathrm{~mm} \mathrm{Hg}$, various kinds of antihypertensive agents can be administered. If you use four or more different types of drugs, a written statement justifying the prescription is necessary.

3. The following combinations are not recommended. If you do decide to use them, only cases for which a valid reason is provided are allowed.

a. Diuretic $+\alpha$ blocker

b. $\beta$ blocker+ACE inhibitor

c. $\beta$ blocker+angiotensin II receptor antagonist

d. ACE inhibitor+angiotensin II receptor antagonist

4. Drugs consisting of the same ingredients are administered once. The administration of compounds is considered to be the same as administering drugs that are components of the compounds.

Target patients: Hypertension patients without comorbidity, as follows.

- Cardiovascular diseases: angina pectoris, myocardial infarction, left ventricular hypertrophy, heart failure, ischaemic heart diseases

- Cerebrovascular diseases, chronic kidney diseases (including proteinuria), diabetes, peripheral blood vessel diseases. were included as covariates. Age was classified into four groups: under 49, 50-59, 60-69, over 70 years. Region of medical facilities which a patient visited was categorised into Seoul, metropolitan and rural. There were two insurance types: health insurance and medical aid. CCI was calculated yearly based on Quan's methods. ${ }^{15}$ Nineteen diseases were classified into scores of 1, 2, 3 and $6 .{ }^{16}$ The CCI per subject was calculated from the sum of all scores. In this study, CCI was grouped as scores of $0,1,2$ and over 3. Combinations of antihypertensive agents represented the number of kinds of antihypertensive drugs that participants took monthly. Combinations of antihypertensive agents are used to adjust the severity of the hypertension, for instance, in cases of resistant hypertension. ${ }^{17}$ These were classified as $0,1,2$ and over 3 .

A subgroup analysis for insurance type was conducted because Medical aid beneficiaries usually overuse healthcare services in Korea. ${ }^{18}$

\section{Statistical methods}

Segmented regression analysis of interrupted time series design was used to assess policy effects with the methods in Wagner $e t a l^{19}$ and Sen $e t a l^{20}$ Our segmented regression analysis equation was in Equation 1:

$$
\begin{aligned}
& \mathrm{Y}_{\mathrm{it}}=\beta_{0}+\beta_{1} \times \text { time }_{\mathrm{t}}+\beta_{2} \times \text { new pricing system } \mathrm{t}+ \\
& \beta_{3} \times \text { time after new pricing system }{ }_{\mathrm{t}}+\beta_{4} \\
& \times \text { new guideline } \mathrm{t}_{\mathrm{t}}+
\end{aligned}
$$

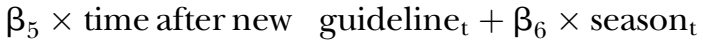

$$
\begin{aligned}
& +\mathrm{X}_{\mathrm{it}}+\mathrm{e}_{\mathrm{it}}
\end{aligned}
$$

Y: dependent variables; i: each patient; t: time period; time: a continuous variable started in January 2011; drug price reduction: a binary variable ( 0 before January 2012; 1 after April 2012); time after drug price reduction: a continuous variable started in April 2012; new guideline: a binary variable ( 0 before January 2013; 1 after February 2013); time after new guideline: a continuous variable started in February 2013; season: seasonality (spring, summer, fall, winter); X: independent variables; e: the error term; New guidelines and time after new guidelines were started in February 2013 because there 
was a 1-month lagged effect of the new guideline. As there is the possibility of seasonal variation in blood pressure, seasonality was included in the equation. ${ }^{21}$

For this segmented regression analysis, each subject's data were aggregated monthly. The unit of analysis is a 'person-month'. Generalised estimation equation (GEE) was conducted using proc genmod in SAS 9.3 with link identity, distribution normal and $A R$ (1). For binary variables, such as drug overutilisation and prohibited combinations, a probit model was used in GEE.

\section{Calculating marginal effects of policies}

As the interpretation of segmented regression analysis is difficult because there are many variables related to time, marginal effects on dependent variables were calculated to display exact effects of policies. $\beta_{2}$ and $\beta_{3}$ were related to the drug price reduction policy. Marginal effects of only the drug price reduction in December 2012 compared to March 2012 can be calculated as $\left(\beta_{2}+\beta_{3} \times 9\right)$. Similarly, the marginal effects of the new guidelines in October 2013 compared to January 2013 can be calculated as $\left(\beta_{4}+\beta_{5} \times 9\right)$. The marginal effects of both policies in December 2013 compared to March 2012 can be calculated as $\left(\beta_{2}+\beta_{3} \times 21+\beta_{4}+\beta_{5} \times 11\right)$.

The coefficient estimates of drug overutilisation and prohibited combinations were calculated in the probit model, as they were needed to transform to marginal effects at the sample means of variables for interpretation. They were calculated with the margins command in Stata V.13. For example, they can be interpreted as increasing probability by amount of $\beta_{5}$ per unit increase.

\section{RESULTS}

Table 1 shows the general participant characteristics in this study. A total of 54295 participants were included and the highest proportion was in the over 70 years age group at 15428 . There were $24842(45.8 \%)$ men and $29453(54.3 \%)$ women. Most of the participants had health insurance $(93.8 \%)$. More than half lived in rural areas $(53.6 \%)$. Combinations of hypertensive agents were scored as $0,1,2$ and over 3, with $14000(6.2 \%)$, 14571 (26.8\%), 10628 (19.6\%) and 15096 (27.8\%) participants.

The monthly trends of dependent variables are displayed in figures 2-4. We did not show the trends for all study populations because they are similar to the trends of the health insurance population which made up most of this study population (93.8\%).

Daily drug utilisation and number of drugs showed a decreasing trend after the guidelines. They were not affected by the drug price reduction. Number of drugs, number of drug overutilisations, and number of prohibited combinations showed decreasing trends after the new guidelines were implemented. The overall utilisation of originators did not change after the introduction of the new policies'(figures 2, and 3). The expenditures remarkably decreased in April 2012 and February 2013

\begin{tabular}{|c|c|c|}
\hline & $\mathbf{N}$ & $(\%)$ \\
\hline \multicolumn{3}{|l|}{ Age (years) } \\
\hline-49 & 8982 & 16.5 \\
\hline $50-59$ & 14975 & 27.6 \\
\hline $60-69$ & 14910 & 27.5 \\
\hline $70-$ & 15428 & 28.4 \\
\hline \multicolumn{3}{|l|}{ Sex } \\
\hline Woman & 29453 & 54.3 \\
\hline Man & 24842 & 45.8 \\
\hline \multicolumn{3}{|l|}{ Region } \\
\hline Seoul & 11831 & 21.8 \\
\hline Metropolitan & 13356 & 24.6 \\
\hline Rural & 29108 & 53.6 \\
\hline \multicolumn{3}{|l|}{ Insurance type } \\
\hline Health insurance & 50942 & 93.8 \\
\hline Medical aid & 3353 & 6.2 \\
\hline \multicolumn{3}{|c|}{ Charlson comorbidity index } \\
\hline 0 & 14000 & 25.8 \\
\hline 1 & 14571 & 26.8 \\
\hline 2 & 10628 & 19.6 \\
\hline $3-$ & 15096 & 27.8 \\
\hline \multicolumn{3}{|c|}{ Combinations of hypertensive agents } \\
\hline 0 & 3295 & 6.1 \\
\hline 1 & 32219 & 59.3 \\
\hline 2 & 14183 & 26.1 \\
\hline 3- & 4598 & 8.5 \\
\hline Total & 54295 & 100.0 \\
\hline
\end{tabular}

for health insurance participants. For Medical aid participants, the expenditures decreased in April 2012 (figure 4).

The trend of daily drug utilisation increased significantly after the drug price reduction, and decreased after the guidelines were implemented. The average number of drugs per month showed an increasing trend after the drug price reduction, but it decreased after the new guidelines. Only the baseline time variable was significant for per cent of original drugs (table 2).

Table 3 shows the results of the segmented regression analysis for expenditures. For expenditures, the effects of the drug price reduction at the time when the policy was implemented were bigger than those of the new guidelines. However, the effects of the new guidelines were bigger than those of the drug price reduction for the trends after the policy was implemented.

The probabilities of drug overutilisation and prohibited combination showed a significant upward trend after the drug price reduction, but they showed a downward trend after the new guidelines (table 4).

Marginal effects for the dependent variables are presented in table 5. Antihypertensive drug costs decreased by $4.2217(26 \%)$ USD in December 2013 as a result of both policies. The effects of the guidelines decreased expenditures, daily drug utilisation and average number of drugs per month more than did the drug price reduction. 
Figure 2 Trends of monthly drug utilisation per patient.

(A) Daily drug utilisation; (B) Average number of drugs; (C) Per cent of original drugs.
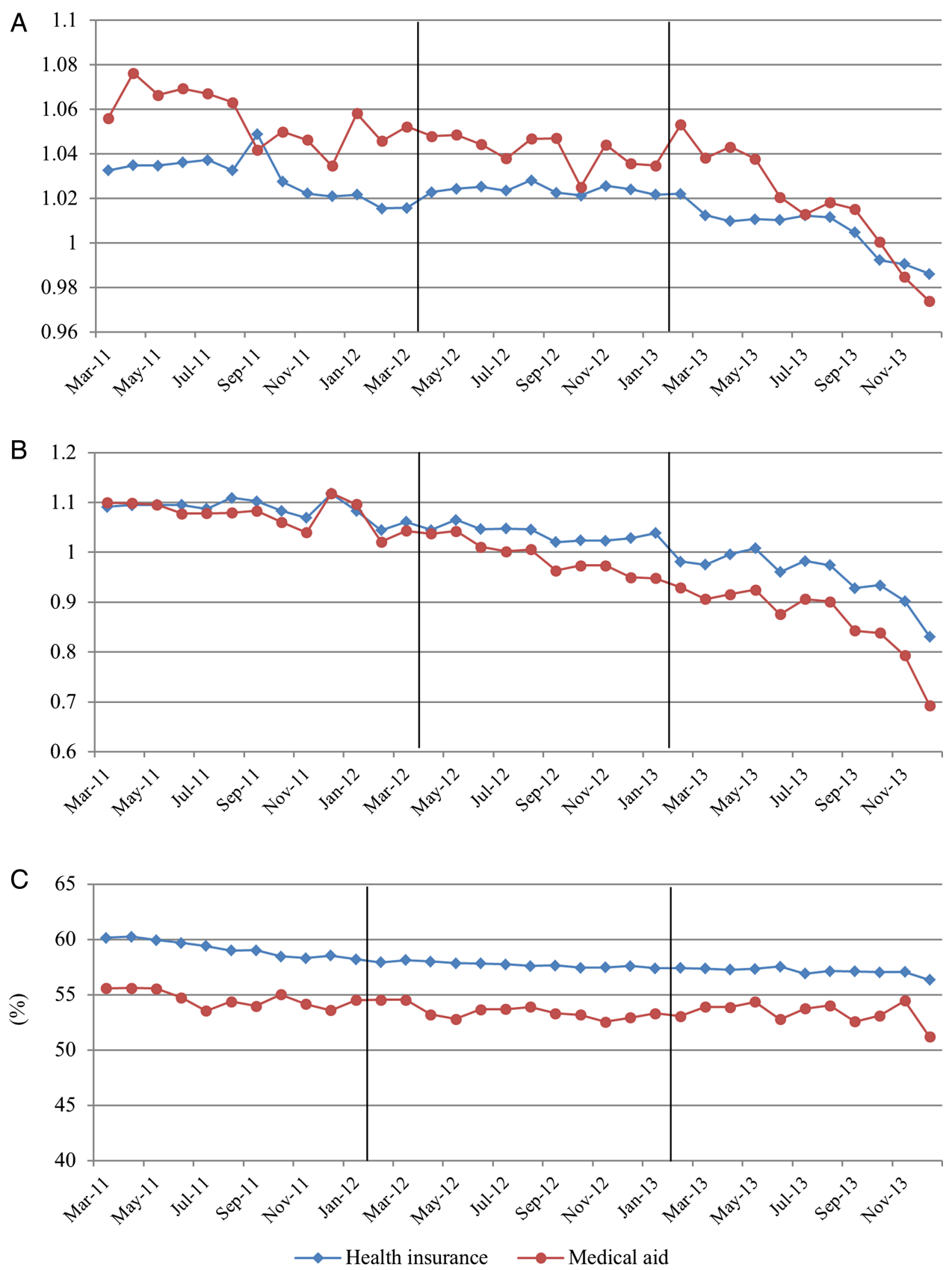

\section{DISCUSSION}

In this study, we identified the policy effects of the drug price reduction and guidelines, which prescribe restriction, on the utilisation and expenditures of antihypertensive drugs.

We used the segmented regression analysis to classify the effects of policies. Segmented regression analysis of interrupted time series analysis is a useful method to evaluate policy evaluation. ${ }^{19}$ It can compare the time series pattern before the intervention with the pattern after the intervention. As systematic changes can occur over time, this analysis is frequently used to measure the degree of change in the use of medical care. ${ }^{19} 2022-25$ Most studies using segmented analysis were analysed with time-aggregated data without considering the personal level. Sen et als $\mathrm{s}^{20}$ study used segmented regression analysis with data aggregated into "person-months." This study was conducted based on Sen et als method, and thus it was able to overcome the limitation mentioned by most studies regarding an unadjusted case-mix. This study employed the GEE model. Model selection between GEE or the mixed model is a matter of debate. ${ }^{26}$ The strength of GEE is that it is a very flexible approach to analyse correlated data from the same participants over time. ${ }^{27} 28$ The limitation of the mixed model is the assumption of residual normality. ${ }^{26} 29$ Thus, the study results were interpreted based on GEE.

For daily drug utilisation results, the baseline time of the effect on daily drug utilisation showed a decreasing trend. This may have been the effect of recommending low doses and multiple antihypertensive combinations. $^{30} 31$ However, daily drug utilisation increased after 
Figure 3 Trends of monthly per cent of drug overutilisation and prohibited combination per patient (A) drug overutilisation; (B) prohibited combination.
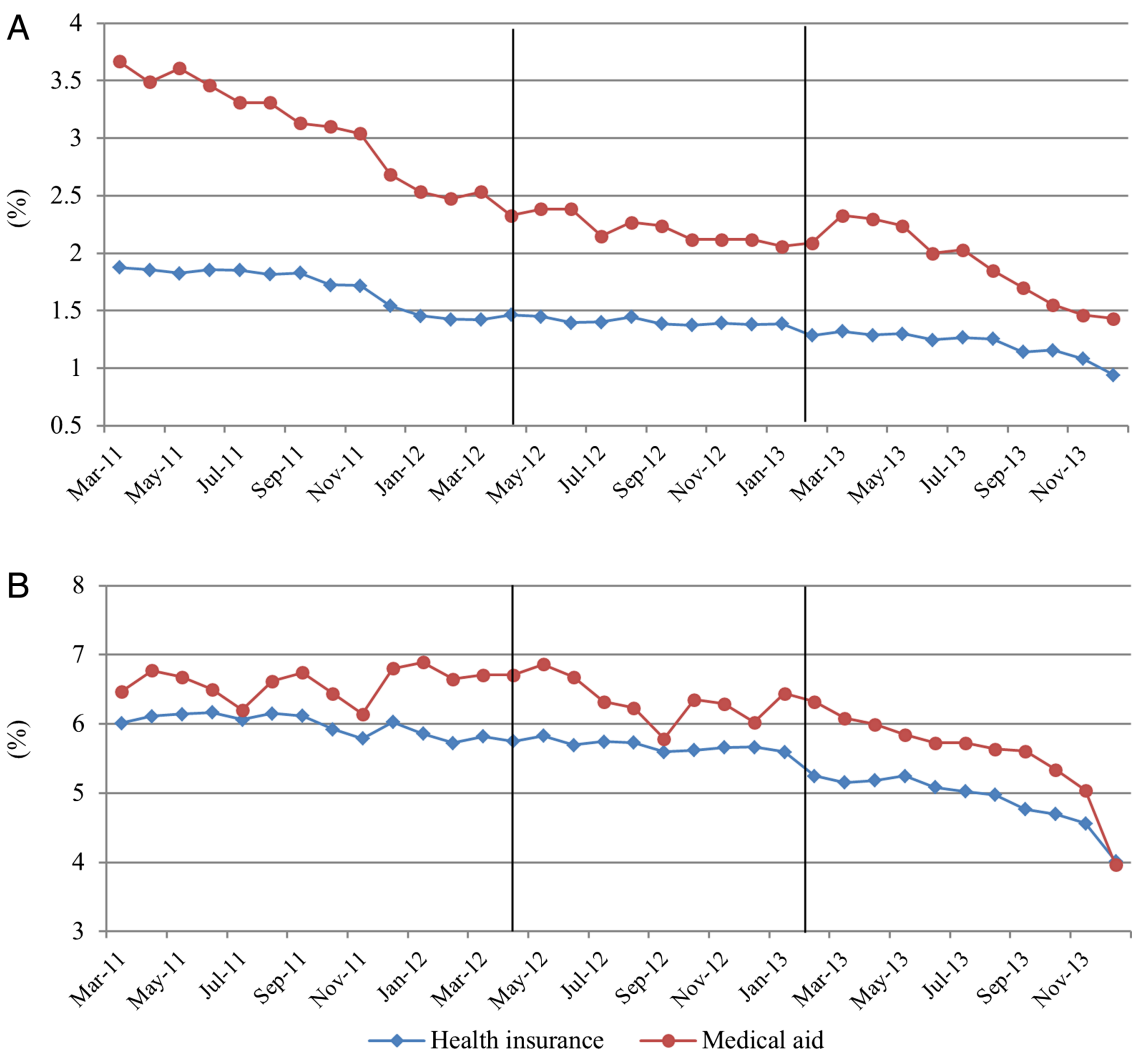

the guidelines were implemented. There were no dosage clauses in the guideline; only clauses for blood pressure conditions and drug combinations are included. This may have led to an increase in the quantity of drugs used per day. However, it changed to a downward trend after the guideline.

At the start of policy implementation, the reduction of expenditures owing to drug price reductions was greater than the impact of the new guidelines. However, over a 9-month period, the new guidelines reduced expenditures and some drug utilization variables more effectively than did the drug price reduction in the segmented regression analysis. This may be because healthcare providers may substitute the drugs whose prices were not reduced and increase utilisation after introduction of the drug price reduction. Thus, the
Figure 4 Trends of monthly expenditures per patient.

(A) Antihypertensive drug costs;

(B) Antihypertensive drug cost per prescribing day.
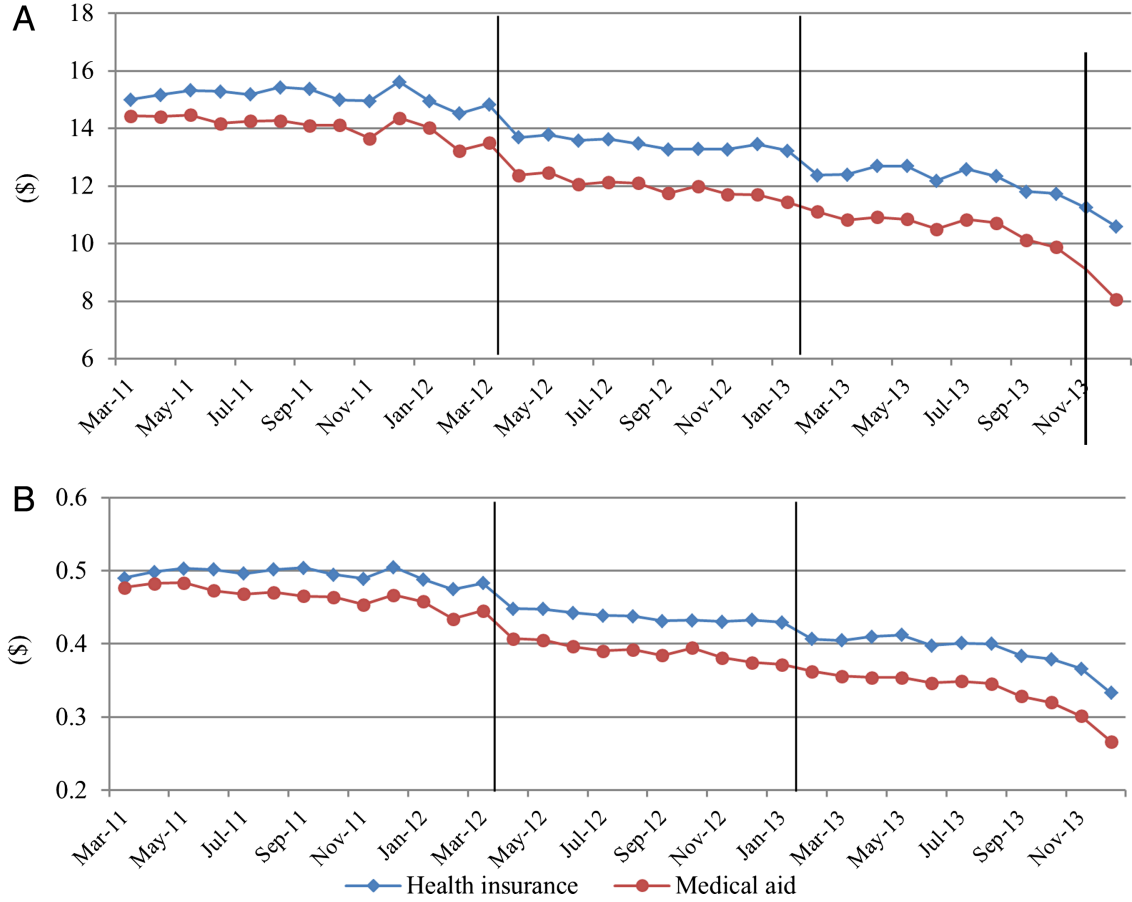
Table 2 Results of the segmented regression analysis for drug utilisation*

\begin{tabular}{|c|c|c|c|c|c|c|c|c|c|c|c|}
\hline & \multirow[b]{2}{*}{ Group } & \multicolumn{2}{|l|}{ Time } & \multicolumn{2}{|c|}{$\begin{array}{l}\text { Drug price } \\
\text { reduction }\end{array}$} & \multicolumn{2}{|c|}{$\begin{array}{l}\text { Time after drug } \\
\text { price reduction }\end{array}$} & \multicolumn{2}{|c|}{ New guideline } & \multicolumn{2}{|c|}{$\begin{array}{l}\text { Time after new } \\
\text { guideline }\end{array}$} \\
\hline & & Estimate & p Value & Estimate & p Value & Estimate & $p$ Value & Estimate & p Value & Estimate & p Value \\
\hline \multirow[t]{3}{*}{ Daily drug utilisation } & All & -0.0016 & $<0.001$ & 0.0018 & 0.225 & 0.0015 & $<0.001$ & 0.0035 & 0.026 & -0.0038 & $<0.001$ \\
\hline & Health insurance & -0.0016 & $<0.001$ & 0.0022 & 0.143 & 0.0015 & $<0.001$ & 0.0027 & 0.104 & -0.0037 & $<0.001$ \\
\hline & Medical aid & -0.0014 & 0.147 & -0.0040 & 0.628 & 0.0007 & 0.689 & 0.0181 & 0.006 & -0.0062 & 0.002 \\
\hline \multirow[t]{3}{*}{ Average number of drugs per month } & All & 0.0047 & $<0.001$ & -0.0265 & $<0.001$ & 0.0016 & $<0.001$ & -0.0073 & 0.004 & -0.0171 & $<0.001$ \\
\hline & Health insurance & 0.0048 & $<0.001$ & -0.0263 & $<0.001$ & 0.0016 & $<0.001$ & -0.0100 & $<0.001$ & -0.0169 & $<0.001$ \\
\hline & Medical aid & 0.0035 & 0.007 & -0.0332 & 0.003 & 0.0012 & 0.566 & 0.0352 & $<0.001$ & -0.0204 & $<0.001$ \\
\hline \multirow[t]{3}{*}{ Per cent of original drugs (\%) } & All & -0.0958 & $<0.001$ & -0.0457 & 0.557 & 0.0156 & 0.454 & 0.0460 & 0.535 & 0.0193 & 0.373 \\
\hline & Health insurance & -0.0971 & $<0.001$ & -0.0416 & 0.603 & 0.0211 & 0.322 & 0.0548 & 0.476 & 0.0064 & 0.774 \\
\hline & Medical aid & -0.1001 & 0.098 & -0.0657 & 0.849 & -0.0470 & 0.637 & -0.1195 & 0.679 & 0.1951 & 0.091 \\
\hline
\end{tabular}

${ }^{\star}$ All results were adjusted by age, sex, region, insurance type, Charlson comorbidity index and combinations of hypertension agents.

\begin{tabular}{|c|c|c|c|c|c|c|c|c|c|c|c|}
\hline & \multirow[b]{2}{*}{ Group } & \multicolumn{2}{|l|}{ Time } & \multicolumn{2}{|c|}{$\begin{array}{l}\text { Drug price } \\
\text { reduction }\end{array}$} & \multicolumn{2}{|c|}{$\begin{array}{l}\text { Time after drug } \\
\text { price reduction }\end{array}$} & \multicolumn{2}{|c|}{ New guideline } & \multicolumn{2}{|c|}{$\begin{array}{l}\text { Time after new } \\
\text { guideline }\end{array}$} \\
\hline & & Estimate & p Value & Estimate & p Value & Estimate & p Value & Estimate & p Value & Estimate & p Value \\
\hline & $\begin{array}{l}\text { Health } \\
\text { insurance }\end{array}$ & 0.0858 & $<0.001$ & -1.3828 & $<0.001$ & -0.0164 & 0.033 & -0.3524 & $<0.001$ & -0.1956 & $<0.001$ \\
\hline & Medical aid & 0.0532 & 0.015 & -1.3792 & $<0.001$ & 0.0142 & 0.679 & 0.2265 & 0.199 & -0.2901 & $<0.001$ \\
\hline \multirow{2}{*}{$\begin{array}{l}\text { Antihypertensive drug cost per prescribing } \\
\text { day (USD) }\end{array}$} & All & 0.0021 & $<0.001$ & -0.0424 & $<0.001$ & -0.0002 & 0.443 & -0.0066 & $<0.001$ & -0.0074 & $<0.001$ \\
\hline & Medical aid & 0.0009 & 0.182 & -0.0453 & $<0.001$ & 0.0011 & 0.318 & 0.0055 & 0.258 & -0.0094 & $<0.001$ \\
\hline
\end{tabular}

${ }^{*}$ All results were adjusted by age, sex, region, insurance type, Charlson comorbidity index and combinations of hypertension agents. 


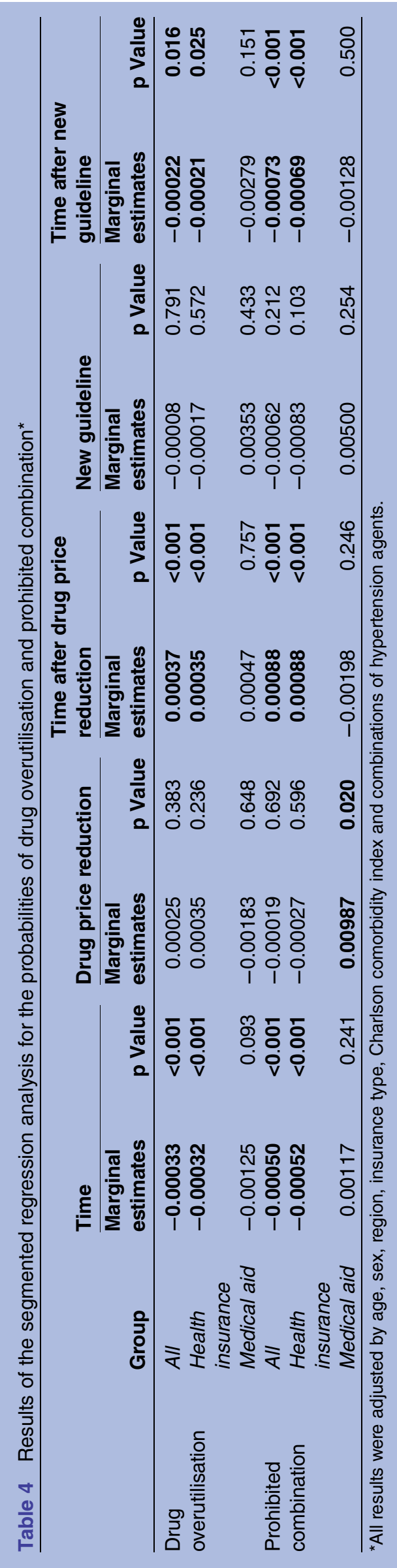

effectiveness of the guidelines improved over time due to the reduction of drug utilisation. Drug price reduction is a direct price control policy, and the new guidelines may be described as a prescribing restriction. A direct price control policy is typically effective to decrease expenditures. ${ }^{32}$ However, some empirical studies reported that it was difficult to control costs, ${ }^{33-35}$ because companies have sought ways to increase sales volumes of drugs that have not been affected by the drug price reduction. On the other hand, drug price control policies linked to extensive demand-side initiatives, including education, financial incentives and switching polices, can reduce expenditures even though volumes increase.$^{36}$ Therefore, there is a need to identify policy effects of drug price control policy on utilisation of drugs which have been not affected by policy.

The unintended impact of this study was that the drug price reduction increased the average number of drugs per month and drug overutilisation and prohibited combination. However, the unintended impacts of the guidelines were unclear. The unintended impacts of restriction policies on the prescription of drugs were not clearly identified, except that they potentially reduced access to certain drugs, including patented drugs within a class when generics were available. ${ }^{37-41}$ The guidelines changed physicians' behaviour such that the new guidelines resulted in desirable trends, because the guidelines covered all antihypertensive drugs.

Drug overutilisation and prohibited combinations increased after the drug price reduction and decreased after the new guidelines. They are related to the effects of the number of types of antihypertensive drugs per month. In the report of the Ministry of Health and Welfare in Korea, ${ }^{42}$ the lower the price reduction rate, the more was the increase in drug utilisation. The utilisation of drugs, which was not affected by the drug price reduction, increased by $12.3 \%$. Most of the combinations for the treatment of hypertension were not affected by the policy. The trend of recommending multiple antihypertensive combinations and the policy effect caused increasing drug overutilisation and prohibited combinations. ${ }^{31}$

Price regulation and other policies including reference pricing for the molecule, generic substitution in pharmacies and encouraging INN prescribing can reduce the prescribing and dispensing of originators. ${ }^{43-46}$ Multiple demand-side policy measures to enhance the prescription of generics in a class versus patented products have also reduced costs while volumes have increased. ${ }^{37} 394748$ Korean drug policy does not use a reference pricing system, and Korean physicians can prescribe only by a specific brand name, not by a non-proprietary name. This is different from the practice in a number of European countries.

The effects of the new guidelines on drug utilisation were higher among Medical aid beneficiaries than among health insurance participants. In figure 3, Medical aid beneficiaries had higher daily drug utilisation than health insurance beneficiaries, but this became similar after the 
Table 5 Marginal effects from results of segmented regression analysis

\begin{tabular}{|c|c|c|c|c|}
\hline & Group & $\begin{array}{l}\text { Drug price reduction } \\
\text { in December } 2012 \\
\text { (compared to March } \\
\text { 2012) }\end{array}$ & $\begin{array}{l}\text { New guidelines } \\
\text { in October } 2013 \\
\text { (compared to } \\
\text { January 2013) }\end{array}$ & $\begin{array}{l}\text { Both policies in } \\
\text { December } 2013 \\
\text { (compared to March 2012) }\end{array}$ \\
\hline Daily drug utilisation & $\begin{array}{l}\text { All } \\
\text { Health insurance } \\
\text { Medical aid }\end{array}$ & $\begin{array}{l}+0.0153 \\
+0.0157 \\
+0.0023\end{array}$ & $\begin{array}{l}-0.0307^{\star} \\
-0.0306 \\
-0.0377^{\star}\end{array}$ & $\begin{array}{l}-0.0050 \\
-0.0043 \\
-0.0394\end{array}$ \\
\hline $\begin{array}{l}\text { Average number of drugs } \\
\text { per month }\end{array}$ & $\begin{array}{l}\text { All } \\
\text { Health insurance } \\
\text { Medical aid }\end{array}$ & $\begin{array}{l}-0.0121^{\star} \\
-0.0119^{\star} \\
-0.0224\end{array}$ & $\begin{array}{l}-0.1612^{\star} \\
-0.1621^{\star} \\
-0.1484^{\star}\end{array}$ & $\begin{array}{l}-0.1883^{\star} \\
-0.1886^{\star} \\
-0.1972\end{array}$ \\
\hline $\begin{array}{l}\text { Per cent of original } \\
\text { drugs }(\%)\end{array}$ & $\begin{array}{l}\text { All } \\
\text { Health insurance } \\
\text { Medical aid }\end{array}$ & $\begin{array}{l}+0.0947 \\
+0.1483 \\
-0.4887\end{array}$ & $\begin{array}{l}+0.2197 \\
+0.1124 \\
+1.6364\end{array}$ & $\begin{array}{l}+0.5402 \\
+0.5267 \\
+0.9739\end{array}$ \\
\hline $\begin{array}{l}\text { Drug overutilisation } \\
\text { (probability) }\end{array}$ & $\begin{array}{l}\text { All } \\
\text { Health insurance } \\
\text { Medical aid }\end{array}$ & $\begin{array}{l}+0.00358 \\
+0.00350 \\
+0.00240\end{array}$ & $\begin{array}{l}-0.00206 \\
-0.00206 \\
-0.02158\end{array}$ & $\begin{array}{l}+0.00544 \\
+0.00522 \\
-0.01912\end{array}$ \\
\hline $\begin{array}{l}\text { Prohibited combination } \\
\text { (probability) }\end{array}$ & $\begin{array}{l}\text { All } \\
\text { Health insurance } \\
\text { Medical aid }\end{array}$ & $\begin{array}{l}+0.00768 \\
+0.00765 \\
-0.00795\end{array}$ & $\begin{array}{l}-0.00719 \\
-0.00704 \\
-0.00652\end{array}$ & $\begin{array}{l}+0.00952 \\
+0.00979 \\
-0.04079\end{array}$ \\
\hline $\begin{array}{l}\text { Antihypertensive drug costs } \\
\text { (USD) }\end{array}$ & $\begin{array}{l}\text { All } \\
\text { Health insurance } \\
\text { Medical aid }\end{array}$ & $\begin{array}{l}-1.5137^{\star} \\
-1.5304^{\star} \\
-1.2514\end{array}$ & $\begin{array}{l}-2.1272^{\star} \\
-2.1128^{\star} \\
-2.3844\end{array}$ & $\begin{array}{l}-4.2217^{\star} \\
-4.2312^{\star} \\
-4.0456\end{array}$ \\
\hline $\begin{array}{l}\text { Antihypertensive drug cost } \\
\text { per prescribing day (USD) }\end{array}$ & $\begin{array}{l}\text { All } \\
\text { Health insurance } \\
\text { Medical aid }\end{array}$ & $\begin{array}{l}-0.0442 \\
-0.0450 \\
-0.0354\end{array}$ & $\begin{array}{l}-0.0732^{*} \\
-0.0731^{*} \\
-0.0791\end{array}$ & $\begin{array}{l}-0.1346 \\
-0.1363 \\
-0.1201\end{array}$ \\
\hline
\end{tabular}

guidelines were introduced. Therefore, the effect on drug utilisation for Medical aid beneficiaries was larger because they used more antihypertensive drugs than recommended by the new guideline. The copayment decreased because of the drug price reduction, and a previous study reported that Medical aid beneficiaries used more drugs than health insurance beneficiaries. ${ }^{49}$ Therefore, the effect on health inequality was low.

This study has several limitations. The follow-up periods were short from the date when the guidelines were implemented. Patients with secondary hypertension were excluded from this study. Thus, these results do not represent all patients with hypertension in Korea. As the unit of analysis was aggregated monthly per person, hospital characteristics were not captured in the analysis. There may remain hospital effects in drug utilisation variables. There was no control in this study. The effects of the guidelines may be combined by the drug price reduction. Since we conducted the segmented regression by period, the results were still similar. The health outcomes were not evaluated in this study. Further study should identify the effects on health outcomes.

\section{CONCLUSION}

The policies saved money. The guidelines, which were issued as a prescribing restriction, were more effective and resulted in fewer unintended impacts than drug price reduction, which was a direct price control policy.
The drug price reduction had strong effects at the implementation of the new policy, but the effects of restrictions on the prescription of drugs became more evident over time. Policymakers should consider the unintended impacts, such as increasing daily drug utilisation and the number of drugs and the comprehensive effects when introducing new policies.

Author affiliations

${ }^{1}$ Department of Healthcare Management, Eulji University, Sungnam, South Korea

${ }^{2}$ Institute of Health Services Research, Yonsei University, Seoul, South Korea ${ }^{3}$ Graduate School of Public Health, Yonsei University, Seoul, South Korea ${ }^{4}$ National Evidence-based Healthcare Collaborating Agency, Seoul, South Korea

${ }^{5}$ Health Insurance Review and Assessment Service, Seoul, South Korea ${ }^{6}$ Department of Preventive Medicine, College of Medicine, Yonsei University, Seoul, South Korea

Acknowledgements The medical research supporting section of Yonsei University and Editage provided English editing support for this paper.

Contributors K-BY developed the research design, analysed the data and drafted the manuscript. SGL and THK contributed to the interpretation of results. SP and JA contributed to the data analysis methods. E-CP contributed to data acquisition and results interpretation.

Funding This research received no specific grant from any funding agency in the public, commercial or not-for-profit sectors.

Competing interests None declared.

Provenance and peer review Not commissioned; externally peer reviewed.

Data sharing statement Extra data can be accessed via the Dryad data repository at http://datadryad.org/ with the doi:10.5061/dryad.p8d5g. 
Open Access This is an Open Access article distributed in accordance with the Creative Commons Attribution Non Commercial (CC BY-NC 4.0) license, which permits others to distribute, remix, adapt, build upon this work noncommercially, and license their derivative works on different terms, provided the original work is properly cited and the use is non-commercial. See: http:// creativecommons.org/licenses/by-nc/4.0/

\section{REFERENCES}

1. Organization for economic co-operation and development. OECD Health Data: Organization for economic co-operation and development (OECD), 2013.

2. Bae EY, Lee EK. Pharmacoeconomic Guidelines and Their Implementation in the Positive List System in South Korea. Value Health 2009;12(Suppl 3):S36-41.

3. Division of standardization for drug use. Ministry of Health and Welfare notification, 2012-155: The guideline for antihypertensive drugs. 2012. http://bit.ly/1qh8Nt1 (accessed 17 Oct 2014).

4. Ministry of Health \& Welfare. Current status and plans of drug price system improvements. 2012. www.mosf.go.kr/_upload/bbs/62/attach/ 20120316140409401.hwp (accessed 17 Oct 2014).

5. Yu SY, Yang BM, Kim JH. New anti-rebate legislation in South Korea. Appl Health Econ Health Policy 2013;11:311-18.

6. Ministry of Health \& Welfare. The announcement of pricing reduction and the new pricing system. 2012. http://www.hira.or.kr/ebook/ 463fa7bd-a59a-4408-966d-967c9e385b43/259_Page_img/extra/ 12320.pdf (accessed 17 Oct 2014).

7. Ministry of Health \& Welfare. Health and Welfare Ministry White Paper. Ministry of Health \& Welfare Affairs, 2012.

8. Cho MH, Yoo KB, Lee HY, et al. The effect of new drug pricing systems and new reimbursement guidelines on pharmaceutical expenditures and prescribing behavior among hypertensive patients in Korea. Health Policy 2015;119:604-11.

9. Ministry of Health \& Welfare. Korea health statistics 2012. Ministry of Health \& Welfare, 2013.

10. Kim KI, Kim Y, Kim HJ, et al. Current status and characteristics of hypertension treatment by primary physicians in Korea: data from Korean epidemiology study on hypertension (KEY study). Am J Hypertens 2008;21:884-9.

11. Kwon S. Thirty years of national health insurance in South Korea: lessons for achieving universal health care coverage. Health Policy Plan 2009;24:63-71.

12. Shin YJ. Policy context of the poor progress of the pro-poor policy: a case study on the Medical-Aid policy during Kim Dae-jung's government (1998-2002) in the Republic of Korea. Health Policy 2006;78:209-23.

13. Shin SC, Kang GW, Kim SW. Simulation on the change of practice pattern after the introduction of 7 diagnosis-related groups prospective payment system in a university hospital. Health Policy Manag 2013;23:103-11.

14. WHO Collaborating Centre for Drug Statistics Methodology Guidelines for ATC classification and DDD assignment 2014. Oslo: WHO, 2013.

15. Quan $\mathrm{H}$, Sundararajan V, Halfon $\mathrm{P}$, et al. Coding algorithms for defining comorbidities in ICD-9-CM and ICD-10 administrative data. Med Care 2005;43:1130-9.

16. Charlson ME, Pompei $\mathrm{P}$, Ales $\mathrm{KL}$, et al. A new method of classifying prognostic comorbidity in longitudinal studies: development and validation. J Chronic Dis 1987;40:373-83.

17. Logan AG, Perlikowski SM, Mente A, et al. High prevalence of unrecognized sleep apnoea in drug-resistant hypertension. $J$ Hypertens 2001;19:2271-7.

18. Shin SM, Kim MJ, Kim ES, et al. Medical Aid service overuse assessed by case managers in Korea. J Adv Nurs 2010;66:2257-65.

19. Wagner AK, Soumerai SB, Zhang F, et al. Segmented regression analysis of interrupted time series studies in medication use research. J Clin Pharm Ther 2002;27:299-309.

20. Sen B, Blackburn J, Morrisey MA, et al. Did copayment changes reduce health service utilization among CHIP enrollees? Evidence from Alabama. Health Serv Res 2012;47:1603-20.

21. Rosenthal T. Seasonal variations in blood pressure. Am J Geriatr Cardiol 2004;13:267-72

22. Law MR, Lu CY, Soumerai SB, et al. Impact of two Medicaid prior-authorization policies on antihypertensive use and costs among Michigan and Indiana residents dually enrolled in Medicaid and Medicare: results of a longitudinal, population-based study. Clin Ther 2010;32:729-41; discussion 16

23. Hartung DM, Carlson MJ, Kraemer DF, et al. Impact of a Medicaid copayment policy on prescription drug and health services utilization in a fee-for-service Medicaid population. Med Care 2008;46:565-72.
24. Soumerai SB, Avorn J, Ross-Degnan D, et al. Payment restrictions for prescription drugs under Medicaid. Effects on therapy, cost, and equity. N Engl J Med 1987;317:550-6.

25. Soumerai SB, Ross-Degnan D, Gortmaker S, et al. Withdrawing payment for nonscientific drug therapy. Intended and unexpected effects of a large-scale natural experiment. JAMA 1990;263:831-9.

26. Hubbard AE, Ahern J, Fleischer NL, et al. To GEE or not to GEE: comparing population average and mixed models for estimating the associations between neighborhood risk factors and health. Epidemiology 2010;21:467-74.

27. Homish GG, Edwards EP, Eiden RD, et al. Analyzing family data a GEE approach for substance use researchers. Addict Behav 2010;35:558-63.

28. Liang KY, Zeger SL. Regression analysis for correlated data. Annu Rev Public Health 1993;14:43-68.

29. Laird NM, Ware JH. Random-effects models for longitudinal data Biometrics 1982;38:963-74.

30. Mahmud A, Feely J. Low-dose quadruple antihypertensive combination: more efficacious than individual agents-a preliminary report. Hypertension 2007;49:272-5.

31. Salahuddin A, Mushtaq M, Materson BJ. Combination therapy for hypertension 2013: an update. J Am Soc Hypertens 2013;7:401-7.

32. Vogler S, Zimmermann N, Leopold C, et al. Pharmaceutical policies in European countries in response to the global financial crisis. South Med Rev 2011;4:69-79.

33. Lee $\mathrm{IH}$, Bloor $\mathrm{K}$, Hewitt $\mathrm{C}$, et al. The effects of new pricing and copayment schemes for pharmaceuticals in South Korea. Health Policy 2012;104:40-9.

34. Kwon HY, Hong JM, Godman B, et al. Price cuts and drug spending in South Korea: the case of antihyperlipidemic agents. Health Policy 2013;112:217-26.

35. Meng Q, Cheng G, Silver L, et al. The impact of China's retail drug price control policy on hospital expenditures: a case study in two Shandong hospitals. Health Policy Plan 2005;20:185-96.

36. Godman B, Wettermark B, Miranda J, et al. Influence of multiple initiatives in Sweden to enhance ARB prescribing efficiency following generic losartan; findings and implications for other countries. Int J Clin Pract 2013;67:853-62.

37. Martikainen JE, Saastamoinen LK, Korhonen MJ, et al. Impact of restricted reimbursement on the use of statins in Finland: a register-based study. Med Care 2010;48:761-6.

38. Green CJ, Maclure M, Fortin PM, et al. Pharmaceutical policies: effects of restrictions on reimbursement. Cochrane Database Syst Rev 2010:CD008654.

39. Moon JC, Godman B, Petzold M, et al. Different initiatives across Europe to enhance losartan utilization post generics: impact and implications. Front Pharmacol 2014;5:219.

40. Voncina L, Strizrep T, Godman B, et al. Influence of demand-side measures to enhance renin-angiotensin prescribing efficiency in Europe: implications for the future. Expert Rev Pharmacoecon Outcomes Res 2011;11:469-79.

41. Hartz I, Sakshaug S, Furu K, et al. Aspects of statin prescribing in Norwegian counties with high, average and low statin consumption -an individual-level prescription database study. BMC Clin Pharmacol 2007;7:14

42. Ministry of Health \& Welfare. 1-year effect of the new drug pricing system. 2013. http://www.mw.go.kr/front_new/al/sal0301vw.jsp? PAR MENU ID $=04 \& M E N U$ ID $=0403 \&$ page $=1 \& C O N T$ SEQ $=288812$ (accessed 17 Oct 2014).

43. Puig-Junoy J. Impact of European pharmaceutical price regulation on generic price competition: a review. Pharmacoeconomics 2010;28:649-63.

44. Dylst $P$, Vulto A, Simoens $S$. Demand-side policies to encourage the use of generic medicines: an overview. Expert Rev Pharmacoecon Outcomes Res 2013;13:59-72.

45. Simoens S. A review of generic medicine pricing in Europe. GaBI J 2012;1:8-12.

46. Vogler $\mathrm{S}$. The impact of pharmaceutical pricing and reimbursement policies on generics uptake: implementation of policy options on generics in 29 European countries- an overview. GaBI J 2012;1:93-100.

47. Godman B, Sakshaug S, Berg C, et al. Combination of prescribing restrictions and policies to engineer low prices to reduce reimbursement costs. Expert Rev Pharmacoecon Outcomes Res 2011;11:121-9.

48. Godman B, Wettermark B, van Woerkom M, et al. Multiple policies to enhance prescribing efficiency for established medicines in Europe with a particular focus on demand-side measures: findings and future implications. Front Pharmacol 2014;5:106.

49. Shin SM, Kim ES, Lee HW. The contributing factors to surplus medicine by long-term users of medical aid in Korea. J Prev Med Public Health 2009;42:403-7. 